\title{
Potensi rumput vetiver (Chrysopongon zizanoides L.) dan kangkung (Ipomoea aquatica Forsk.) sebagai agen fitoremediasi limbah industri kayu
}

\section{Potential of vetiver (chrysopongon zizanoides 1.) and kangkung (ipomoea aquatica forsk.) for agent phytoremediation of wood industry waste}

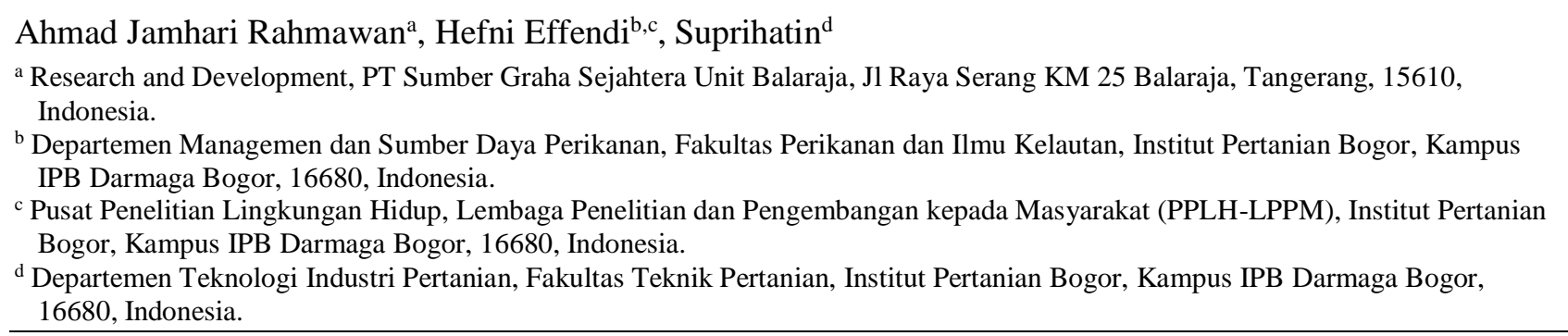

\section{Article Info:}

Received: 06 - 05 - 2018

Accepted: 16 - 05 - 2019

Keywords:

Phenol, growth rate, correlation, mathematical models.

Corresponding Author: Ahmad Jamhari Rahmawan Research and Development, PT Sumber Graha Sejahtera Unit Balaraja, Jl Raya Serang KM 25 Balaraja, Tangerang, 15610, Indonesia;

Email: jamharigtm@gmail.com

\begin{abstract}
Wood industry produces a large amount of waste water that contains various pollutants. These pollutants are mostly dangerous for the environment. This research work aims to analyze the ability of phytoremediation for reducing pollutants in wood industrial waste water. These experiments usee Chrysopongon zizanoides L. and Ipomoea aquatica Forsk as phytoremediation agents. The ability was evaluated from the improved quality of wood industrial wastewater and the growth rate of $C$. zizanioides (L.) and I. aquatica Forsk in wood industrial wastewater. Analysis was conducted by measuring the removal efficiency of pollutants in wood industrial wastewater, the correlation between the reduced pollutants concentrations in the waste water and plant growth rate. Furthermore, a mathematical model is developed to predict the potential of $C$. zizanioides $(L$.) and I. aquatica Forsk for wood industrial wastewater. The result showed that C.zizanioides L. and I aquatica Forsk were potential phytoremediation agent. The removal efficiency for C.zizanioides $L$. and I aquatica Forsk are respectively as follows: $66.19 \%$ and $41.18 \%$, TSS $58.51 \%$ and $45.38 \%$, COD $70.07 \%$ and $40.37 \%$, Total Amonia Nitrogen (TAN) $63.70 \%$ and $66.96 \%, \mathrm{NH}_{3}$ $96.16 \%$ and $88.79 \%$, and $\mathrm{PO}_{4}{ }^{3-} 53.90 \%$ and $38.38 \%$. Relative Growth Rate ( $R G R)$ of C. zizanioides $(0.011 \pm 0.002 \mathrm{~g} /$ day $)$ is better than I. aquatica Forsk $(0.007 \pm 0.001 \mathrm{~g} /$ day). Daily Growth Rate (DGR) of C. zizanioides $(0.019 \pm 0.003 \mathrm{~cm} /$ day) is better than I. aquatica Forsk $(0.012 \pm 0.006 \mathrm{~cm} /$ day $)$. TSS, $\mathrm{COD}, \mathrm{NH}_{3}, \mathrm{NO}_{3}^{-}$, and phenol have a negative correlation to plant growth (based on wet weight and root length). The developed mathematical models can be used to predict the phytoremediation potential of C. zizanioides $(L$.) and I. aquatica Forsk in degrading COD, TSS, and phenols of wood industrial waste.
\end{abstract}

How to cite (CSE Style $8^{\text {th }}$ Edition):

Rahmawana AJ, Effendi H, Suprihatin. Potensi rumput vetiver (Chrysopongon zizanoides L.) dan kangkung (Ipomoea aquatica Forsk.) sebagai agen fitoremediasi limbah industri kayu. JPSL 9(4): 904-919. http://dx.doi.org/10.29244/jps1.9.4.904-919. 


\section{PENDAHULUAN}

Limbah industri kayu terdiri dari 3 jenis, yaitu limbah padatan, limbah udara, dan limbah cair. Limbah cair yang dihasilkan dalam proses produksi kayu lapis secara umum berasal dari pencucian mesin glue spreader dan peralatan produksi lainnya, sehingga komposisi yang terkandung dalam limbah cair yang dihasilkan tergantung jenis perekat yang digunakan. PT Sumber Graha Sejahtera merupakan perusahaan kayu lapis yang menggunakan bahan perekat urea formaldehida dan fenol formaldehida, sehingga jenis limbah cair yang dihasilkan mengandung fenol.

Fenol merupakan salah satu polutan dalam limbah cair industri kayu yang berpotensi mengganggu lingkungan. Keberadaan fenol di air dapat menimbulkan bau tidak sedap, bersifat racun dan korosif, menyebabkan gangguan kesehatan manusia dan kematian pada organisme. Dengan demikian, pemulihan fenol pada limbah cair industri perlu dilakukan sebelum dibuang keperairan luas.

Metode yang banyak digunakan dalam pemulihan fenol adalah ekstraksi pelarut, adsorpsi menggunakan karbon aktif, oksidasi kimia dan degradasi mikroba (Klibanov et al. 1983). Metode pemulihan limbah cair PT Sumber Graha Sejahtera saat ini adalah dengan tiga tahapan, yaitu secara kimia, mekanis (penyaringan), dan biologis (mikroorganisme). Metode tersebut memiliki beberapa kekurangan diantaranya adalah membutuhkan biaya yang tinggi dan kurang efektif pada beberapa kondisi. Sehingga perlu dilakukan penelitian lebih mendalam untuk mengatasi permasalahan tersebut.

Fitoremediasi dengan tanaman merupakan pendekatan secara biologis dalam memulihkan media lingkungan baik tanah maupun perairan yang murah, ramah lingkungan, mampu mereduksi volume kontaminan, serta memberikan keuntungan bagi kesehatan masyarakat (Terry and Banuelos 2010). Tanaman mempunyai kemampuan menyerap, mengakumulasi, memanipulasi, dan mendektofikasi polutan organik atau anorganik. Beberapa polutan dapat digunakan dalam proses fisiologis tanaman. Beberapa penelitian menunjukkan, tanaman yang memiliki akar berbulu seperti Daucus carota (Araujo et al. 2002), Brassica napus (Agostini et al. 2003) dan Brassica juncea (Singh et al. 2006) memproduksi Peroksidase telah digunakan dan terbukti menghilangkan fenol atau turunannya dari larutan.

Contoh tanaman yang dapat digunakan sebagai agen fitoremediasi adalah vetiver (Crysopongon zizanoides L.) dan kangkung (Ipomoea aquatica Forsk). Vetiver dilaporkan memiliki kemampuan dalam mereduksi material organik seperti COD, BOD, amonia, dan juga logam seperti $\mathrm{Zn}(90 \%)$, As (60\%), $\mathrm{Pb}$ (30$71 \%$ ), $\mathrm{Hg}$ (13-15\%), serta fenol (100-100 $\mathrm{mg} \mathrm{L}^{-1}$ ) (Truong 2000; Singh et al 2008). Kangkung memiliki kemampuan dalam mereduksi kebutuhan oksigen secara biologis (BOD), permintaan oksigen kimia (COD), padatan tersuspensi total (TSS), Klorofil ' A ' dan logam seperti Cd dan Cr serta nutrisi seperti N dan P Dari limbah cair (Hu et al 2008; Wang et al 2008; Chen et al 2010).

Penelitian ini bertujuan untuk menganalisis potensi tanaman vativer dan kangkung sebagai agen fitoremediasi dalam menyisikan polutan limbah cair industri kayu, memprediksi tren potensi tanaman vetiver dan kangkung untuk limbah cair industri kayu dengan model matematika, serta menganalisis korelasi polutan dan laju pertumbuhan tanaman.

\section{METODE}

\section{Bahan Penelitian}

Akar C. zizanioides (L.) direndam dalam larutan $0.3 \%$ hidrogen peroksida selama 20 menit, kemudian dibilas dengan akuades (Aibibu et al. 2010). Tanaman dipilih berdasarkan perkiraan umur yang sama, memiliki tinggi antara 10-15 cm kemudian ditimbang bobotnya sekitar 30 gram/rumpun.

Benih I. aquatica Forsk disterilkan dengan larutan $\mathrm{H}_{2} \mathrm{O}_{2}$ 10\% Selama 15 menit lalu dicuci dengan akuades, Selanjutnya benih direndam dalam akuades selama 8 jam pada suhu $50{ }^{\circ} \mathrm{C}$ dan dicuci dengan akuades (Hu et al. 2008). Benih ditabur pada spon yang terdapat pada nampan dan ditutup dengan kain hitam. Perkecambahan ini dilakukan pada kondisi gelap selama 3 hari. Benih yang layak berkecambah diberi 
penyinaran matahari pagi hari. Ketika bibit memiliki panjang $5 \mathrm{~cm}$ dipindahkan pada sistem hidroponik. Tanaman dipilih berdasarkan panjang $(12 \pm 2 \mathrm{~cm})$ dan berat yang sama $(12 \pm 5 \mathrm{~g} /$ rumpun $)$.

\section{Metode Pengumpulan Data}

Pengumpulan data dalam penelitian ini meliputi kualitas air berdasarkan kondisi beberapa parameternya (Suhu, TSS, pH, COD, TAN, $\mathrm{NH}_{3}, \mathrm{NH}_{4}{ }^{+}, \mathrm{NO}_{3}, \mathrm{PO}_{4}$, dan Fenol), penyisihan polutan, serta laju pertumbuhan tanaman. Penentuan parameter kualitas air didasarkan pada didasarkan pada KLHK No 5 tahun 2014 tentang Baku Mutu Air Limbah. Analisis kualitas air dilakukan berdasarkan Standard APHA (2012). Pengamatan dan pengumpulan data dilakukan satu minggu sekali selama empat minggu $(0,7,14,21$, dan 28 hari).

Penghitungan konsentrasi amonia $\mathrm{NH}_{3}$ dan $\mathrm{NH}_{4}{ }^{+}$dilakukan berdasarkan data total amonia nitrogen (TAN) yang diperoleh dengan melibatkan nilai pKa (Tabel 1) dan pH (Strickland and Parsons 1972).

Tabel 1 Nilai pKa Berdasarkan Nilai Suhu.

\begin{tabular}{|c|c|c|c|c|c|c|}
\hline Suhu $\left({ }^{\circ} \mathrm{C}\right)$ & 5 & 10 & 15 & 20 & 25 & 30 \\
\hline $\mathrm{pKa}$ & 9.90 & 9.73 & 9.56 & 9.40 & 9.24 & 9.09 \\
\hline
\end{tabular}

\section{Metode Analisis Data}

Analisis data yang digunakan dalam penelitian ini adalah analisis statistik, penyisihan polutan, model matematika, laju pertumbuhan tanaman, dan korelasi pearson. Penelitian ini dilakukan dengan menggunakan metode eksperimental di laboratorium dengan rancangan percobaan menggunakan rancangan acak lengkap (RAL) in time. Mengacu pada beberapa penelitian sebelumnya (Singh et al. 2008; Lee et al. 2017; Jampeetong etal. 2012), peubah yang digunakan adalah jenis tanaman dengan 3 perlakuan (kontrol, akar wangi dan kangkung air), masing-masing perlakuan diulang sebanyak 3 kali. Sedangkan pengamatan dilakukan sebanyak 5 kali, yaitu saat dimulai (hari ke-0), hari ke-7, hari ke-14, hari ke-21, dan hari ke-28.

Laju pertumbuhan tanaman yang diamati dalam penelitian ini meliputi perubahan berat dan panjang akar tanaman selama priode pengamatan. Pengamatan laju pertumbuhan berat tanaman ditentukan berdasarkan persamaan Hunt (2017), sebagai berikut:

$$
\mathrm{RGR}=\frac{\ln \mathrm{W}_{\mathrm{i}}-\ln \mathrm{W}_{0}}{\mathrm{t}_{\mathrm{i}}-\mathrm{t}_{0}}
$$

Dimana RGR : Laju pertumbuhan relatif tanaman, $\mathrm{W}_{\mathrm{i}}$ : Berat basah tanaman setelah perlakuan (hari ke 28), dan $\mathrm{W}_{0}$ : Berat basah tanaman sebelum perlakuan (hari ke-0)

Pengamatan laju pertumbuhan panjang akar tanaman dilakukan berdasarkan persamaan Ridha dan Cruz (2001) sebagai berikut:

$$
\mathrm{DGR}=\frac{\ln \mathrm{H}_{\mathrm{i}}-\ln \mathrm{H}_{0}}{\mathrm{t}_{\mathrm{i}}-\mathrm{t}_{0}}
$$

Dimana RGR : Laju pertumbuhan akar tanaman, $\mathrm{W}_{\mathrm{i}}$ : Panjang akar tanaman setelah perlakuan (hari ke 28), dan $\mathrm{W}_{0}$ : Panjang akar tanaman sebelum perlakuan (hari ke-0).

Penyisihan polutan limbah cair selama periode pengamatan, dihitung dengan menggunakan rumus Removal efficiency sebagai berikut (Khan et al. 2009):

$$
\mathrm{R}=\left(\frac{\mathrm{I}-\mathrm{F}}{\mathrm{I}}\right) \times 100 \%
$$

Dimana R : Removal efficiency (\%), I : Konsentrasi parameter awal, dan F : Konsentrasi parameter akhir 
Model matematika digunakan untuk mengetahui tren potensi tanaman vetiver dan kangkung dalam penyisian polutan dilakukan dengan menggunakan model matematika berdasarkan persamaan Kumar et al. (2005):

$$
\mathrm{P}=\mathrm{P}_{0} \exp (\mu \mathrm{t})
$$

Dimana $\mathrm{P}$ adalah potensi fitoremediasi tanaman pada waktu $\mathrm{t}(0,7,14,21$, dan 28 hari). $\mu$ adalah konstanta, dicari berdasarkan rumus sebagai berikut:

$$
\begin{gathered}
\mu_{\mathrm{i}}=\left\{\ln \left(\mathrm{P}_{\mathrm{i}} / \mathrm{P}_{0}\right)\right\} / \mathrm{t}_{\mathrm{i}}, \operatorname{dimanai}=1,2,3, \ldots \mathrm{N} \\
\mu=\frac{\sum_{1}^{\mathrm{N}} \mu_{\mathrm{i}}}{\mathrm{N}}
\end{gathered}
$$

Korelasi pearson digunakan untuk mengetahui korelasi antara polutan dan laju pertumbuhan tanaman. Analisis korelasi pearson dilakukan berdasarkan persamaan:

$$
\mathrm{r}=\frac{\sum \mathrm{xy}-\frac{\left(\sum \mathrm{x}\right)\left(\sum \mathrm{y}\right)}{\mathrm{n}}}{\sqrt{\left(\sum \mathrm{x}^{2}-\frac{\left(\sum \mathrm{x}\right)^{2}}{\mathrm{n}}\right)\left(\sum \mathrm{y}^{2}-\frac{\left(\sum \mathrm{y}\right)^{2}}{\mathrm{n}}\right)}}
$$

Dimana $\mathrm{r}$ : Koefisien korelasi pearson, $\mathrm{x}$ : Variable $\mathrm{x}$, dan $\mathrm{y}$ : Variable $\mathrm{y}$.

\section{HASIL DAN PEMBAHASAN}

\section{Penyisihan Polutan}

\section{Suhu}

Suhu merupakan faktor yang berpengaruh terhadap proses fitoremediasi, pertumbuhan tanaman serta proses dekomposis bahan organik (Effendi et al. 2015). Selain itu, suhu juga juga berpengaruh terhadap proses nitrifikasi. Menurut Crab et al (2007) proses nitrifikasi akan berlangsung baik pada suhu $25-35{ }^{\circ} \mathrm{C}$, karena pada kisaran tersebut bakteri nitrifikasi dapat tumbuh dengan baik.

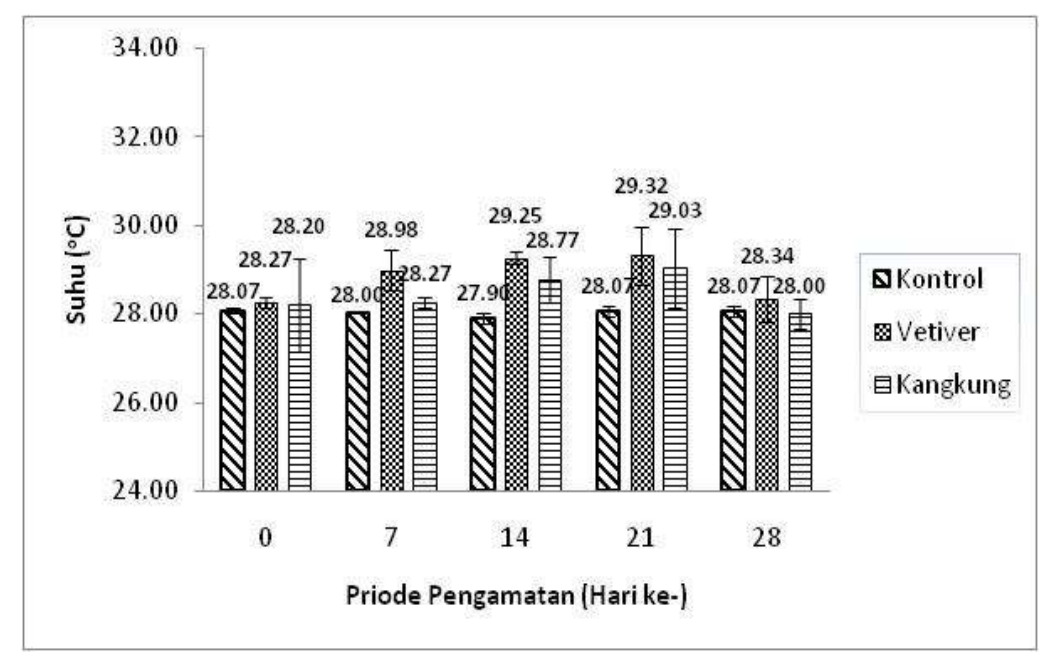

Gambar 1 Perubahan parameter kualitas air suhu.

Suhu limbah cair selama pengamatan pada perlakuan kontrol, vetiver, dan kangkung adalah $28-28.07^{\circ} \mathrm{C}$, 28.27-29.32 ${ }^{\circ} \mathrm{C}$, dan $28-29.03{ }^{\circ} \mathrm{C}$ (Gambar 1). Tanaman vetiver dapat tumbuh dengan baik pada suhu $17.27^{\circ} \mathrm{C}$ (Surtiningsih. 2009)dan tanaman kangkung $25-30{ }^{\circ} \mathrm{C}$ (Indah et al. 2014). Kondisi suhu selama penelitian optimal untuk tanaman vetiver dan kangkung. Hasil analisis statistik menunjukkan bahwa tanaman vetiver dan kangkung memberikan pengaruh yang signifikan $(\mathrm{p}<0.05)$. 
$p H$

$\mathrm{pH}$ atau derajat keasaman menunjukkan tingkat keasaman atau kebasaan dari suatu larutan dengan cara mengukur konsentrasi ion hidrogen $\left(\mathrm{H}^{+}\right)$yang terdapat pada larutan tersebut. $\mathrm{pH}$ dalam limbah industri mempengaruhi pertumbuhan tanaman dan degradasi senyawa organik (Effendi. 2003).

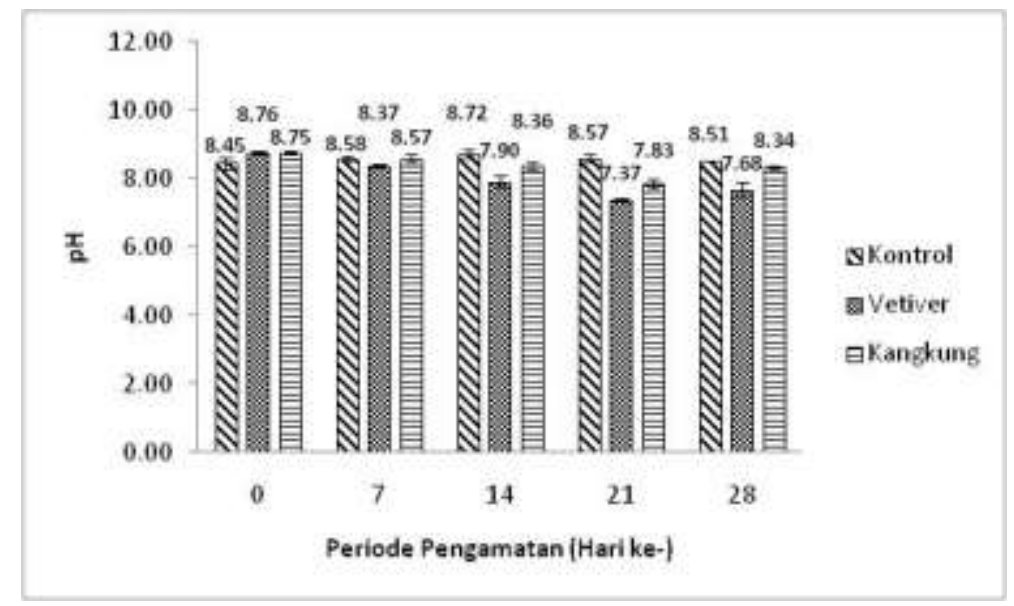

Gambar 2 Perubahan parameter kualitas air $\mathrm{pH}$.

pH limbah cair selama pengamatan pada perlakuan kontrol, vetiver, dan kangkung adalah 7.83-8.75, 7.378.76, dan 8.51-8.72 (Gambar 2). Nilai tersebut sesuai baku mutu limbah untuk industri kayu lapis yang mensyaratkan nilai pH berkisar antara 6-9 (KLHK No 5 tahun 2014). Tanaman vetiver dapat tumbuh pada kondisi lingkungan dengan pH 6-9 (Sighet al. 2014) dan tanaman kangkung 5.5-7 (Lestari. 2013). Kondisi pH selama penelitian kurang optimal untuk tanaman kangkung, sehingga pertumbuhan kangkung cencerung lebih lambat dibandingkan vetiver.

Hasil analisis statistik menunjukkan bahwa tanaman vetiver dan kangkung memberikan pengaruh berbeda nyata $(\mathrm{p}<0.05)$ terhadap perubahan $\mathrm{pH}$ pada limbah industri. Meningkatnya nilai $\mathrm{pH}$ disebabkan oleh proses fotosintesis yang dilakukan oleh tanaman (Effendi. 2003). Sedangkan penurunan $\mathrm{pH}$ dapat terjadi karena ion $\mathrm{H}+$ yang disebabkan oleh pembusukan bagian tanaman yang rontok, dan proses oksidasi pembentukan sulfat (Rahadian et al. 2017).

\section{Total Suspended Solid (TSS)}

TSS adalah padatan tersuspensi yang terdapat pada limbah dengan ukuran kurang dari 0.45 mikron (Mulia, 2005). Material tersuspensi dapat mengakibatkan kekeruhan yang dapat menghalangi cahaya matahari masuk ke dalam tanaman air (Purnamawati, 2015).

Konsentraasi TSS selama pengamatan berkisar antara 97.50-235.00 mg/L relatif menurun (Gambar 3). Pada akhir pengamatan (hari ke-28) konsentrasi TSS perlakuan kontrol, vetiver, dan kangkung adalah 187.50 $\mathrm{mg} / \mathrm{L}, 97.50 \mathrm{mg} / \mathrm{L}$, dan $128.00 \mathrm{mg} / \mathrm{L}$. Nilai tersebut diatas baku mutu yang mensyaratkan nilai TSS kurang dari $50 \mathrm{mg} / \mathrm{L}$ (KLHK No 5 tahun 2014). Penurunan konsentrasi TSS disebabkan oleh penguraian senyawa organik secara alamiah dan penyerapan oleh tanaman. Menurut Fachrurozi et al. (2010) pengurangan nilai TSS disebabkan karena partikel dengan massa yang cukup berat akan mengendap pada bagian reaktor, sedangkan yang cukup ringan dan melayang akan menempel pada bagian akar. 


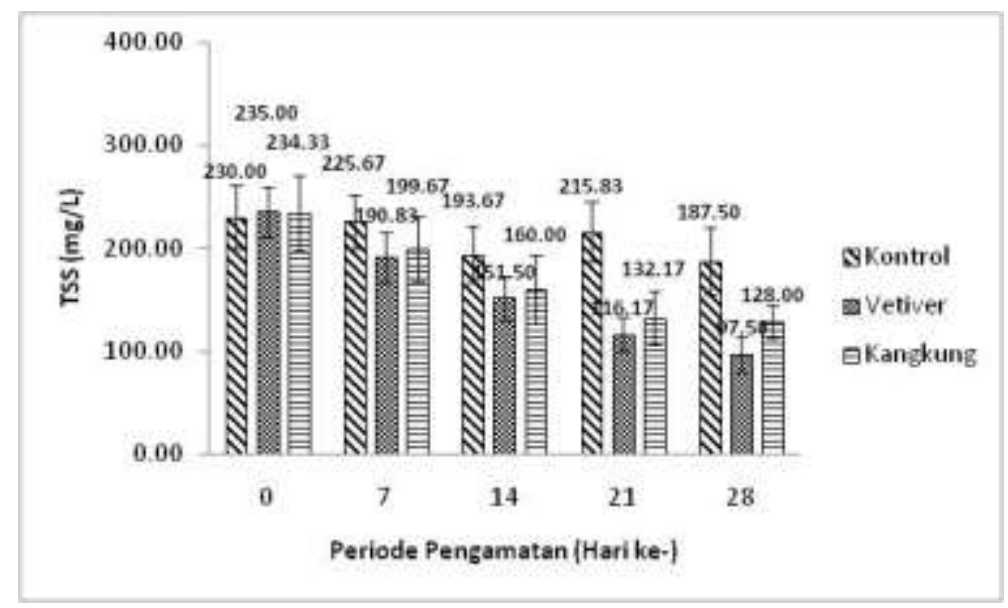

Gambar 3 Perubahan parameter kualitas air TSS.

Hasil analisis statistik menunjukkan bahwa tanaman vetiver dan kangkung memberikan pengaruh yang tidak signifikan $(p>0.05)$, namun berpengaruh signifikan $(p<0.05)$ dengan kontrol. Pemanfaatan tanaman vetiver dan kangkung sebagai agen fitoremediasi efektif dalam menurunkan konsentrasi TSS dalam limbah cair. Nilai removal efficiency pada perlakuan kontrol, vetiver, dan kangkung adalah $18.48 \%, 58.51 \%$, dan $45.38 \%$.

\section{Chemical Oxygen Demand (COD)}

COD adalah nilai yang menunjukkan jumlah oksigen untuk mengoksidasi senyawa organik yang terdapat pada 1 liter larutan (Alaerts dan Santika, 1987) yang dinyatakan dalam satuan mg/l. Menurut Mulia (2005), senyawa organik dalam COD meliputi senyawa yang dapat diolah secara biologis (biodegradable) dan tidak dapat diolah secara biologis (non-biodegradable).

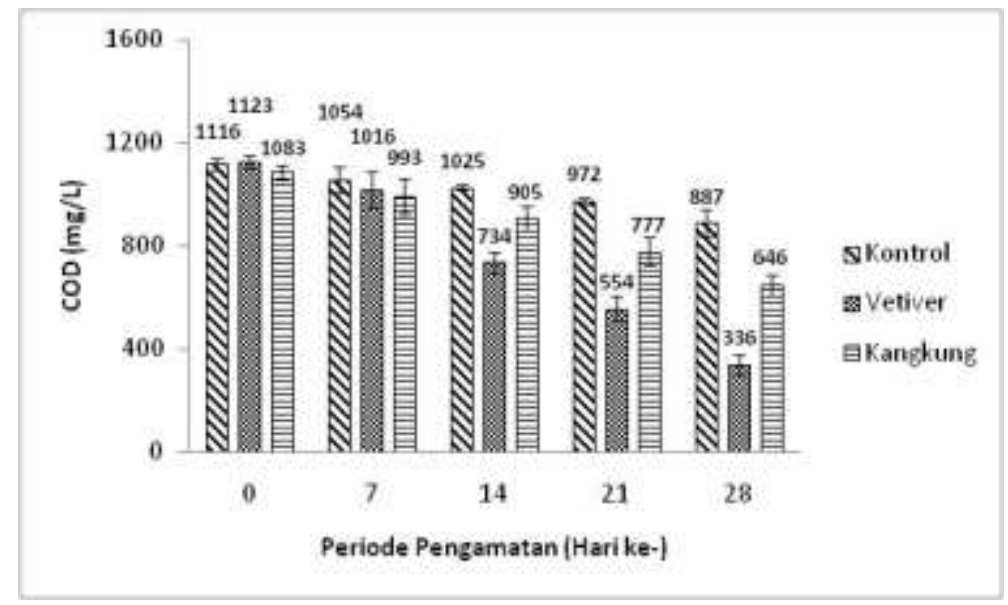

Gambar 4 Perubahan parameter kualitas air COD.

Konsentrasi COD selama pengamatan adalah 336 - $1123 \mathrm{mg} / \mathrm{L}$ dan cenderung menurun pada semua perlakuan (Gambar 4). Pada akhir pengamatan (hari ke-28) konsentrasi COD perlakuan kontrol, vetiver, dan kangkung adalah $887 \mathrm{mg} / \mathrm{L}, 336 \mathrm{mg} / \mathrm{L}$, dan $646 \mathrm{mg} / \mathrm{L}$. Nilai tersebut diatas baku mutu air limbah industri kayu lapis yang mensyaratkan nilai COD kurang dari $125 \mathrm{mg} / \mathrm{L}$ (KLHK No 5 tahun 2014). Penurunan konsentrasi COD diduga karena adanya proses penguraian senyawa organik secara alamiah dan penyerapan oleh tanaman pada limbah cair. Rahadian et al (2017) menyatakan oksigen dalam limbah cair digunakan dalam proses oksidasi senyawa organik menjadi senyawa yang sederhana, sehingga mudah diserap oleh tanaman. Menurut Gunawan (2009) akar tanaman memegang peranan penting dalam mengurangi atau menyerap kandungan BOD dan COD. 
Hasil analisis statistik menunjukkan bahwa perlakuan memeberikan pengaruh signifikan $(\mathrm{p}<0.05)$. Pemanfaatan tanaman vetiver dan kangkung sebagai agen fitoremediasi efektif dalam menurunkan konsentrasi COD dalam limbah cair. Nilai removal efficiency COD pada perlakuan kontrol, vetiver, dan kangkung adalah $20.54 \%, 40.37 \%$, dan $70.07 \%$.

\section{Total Amonia Nitrogen (TAN)}

Amonia di perairan dapat berasal dari dekomposisi bahan organik yang banyak mengandung senyawa nitrogen (protein). Ammonia yang terukur dalam penelitian adalah ammonia total yang terdiri atas $\mathrm{NH}_{3}$ dan $\mathrm{NH}_{4}^{+}$.

Konsentrasi ammonia total selama priode pengamatan berkisar antara 0.86-2.61 $\mathrm{mg} / \mathrm{L}$. Pada akhir pengamatan (hari ke-28) konsentrasi TAN perlakuan kontrol, vetiver, dan kangkung adalah adalah $2.05 \mathrm{mg} / \mathrm{L}$, $1.98 \mathrm{mg} / \mathrm{L}$, dan $1.94 \mathrm{mg} / \mathrm{L}$. Nilai tersebut dibawah baku mutu limbah industri kayu lapis yang mensyaratkan nilai ammonia total kurang dari $4 \mathrm{mg} / \mathrm{L}$ (KLHK No 5 tahun 2014). Dekomposisi bahan organik yang mengandung nitrogen umumnya dilakukan oleh mikroba. Reduksi ammonia terjadi melalui proses oksidasi ammonia menjadi ammonium, nitrit, dan nitrat (nitrifikasi) pada kondisi aerob dengan bantuan bakteri Nitrobacter (Crab et al. 2007). Proses nitrifikasi akan berjalan dengan baik pada suhu $25-35{ }^{\circ} \mathrm{C}$ dan $\mathrm{pH} 7,5-$ 8,6, karena pada kisaran tersebut bakteri nitrifikasi dapat tumbuh dengan baik (Crab et al. 2007; Hargreaves. 1998). Selama priode pengamatan suhu air limbah berkisar $28-29.10^{\circ} \mathrm{C}$ dan $\mathrm{pH} 7.37-8.76$, sehingga proses nitrifikasi berjalan dengan baik.

Hasil analisis statistik menunjukkan bahwa perlakuan tidak berpengaruh signifikan ( $>0.05)$. Pemanfaatan tanaman vetiver dan kangkung sebagai agen fitoremediasi tidak efektif dalam menurunkan konsentrasi TAN dalam limbah cair. Nilai removal efficiencyTAN pada perlakuan kontrol, vetiver, dan kangkung adalah $55.48 \%, 63.70 \%$, dan $66.96 \%$.

\section{Amonia Bebas $\left(\mathrm{NH}_{3}\right)$}

Amonia bebas merupakan bentuk nitrogen yang tidak terionisasi dan toksik terhadap organisme akuatik (Effendi. 2003). Hasil penelitian menunjukkan bahwa nilai ammonia bebas selama pengamatan berkisar antara 0.03-0.75 mg/L (Gambar 5).

Konsentrasi ammonia bebas cenderung fluktuatif selama priode pengamatan. Pada akhir pengamatan (hari ke-28) konsentrasi ammonia bebas perlakuan kontrol, vetiver, dan kangkung adalah $2.05 \mathrm{mg} / \mathrm{L}, 1.98 \mathrm{mg} / \mathrm{L}$, dan $1.94 \mathrm{mg} / \mathrm{L}$. Konsentrasi ammonia bebas dalam limbah akan meningkat dengan meningkatnya suhu dan pH. Wahyuningsih et al. (2015) menyatakan bahwa 30\% dari ammonia total akan berubah menjadi ammonia bebas pada $\mathrm{pH}$ diatas 8.75 . Selama priode pengamatan nilai $\mathrm{pH}$ berkisar antara 7.37-8.76, sehingga konsentrasi ammonia bebas relatif kecil dalam limbah cair.

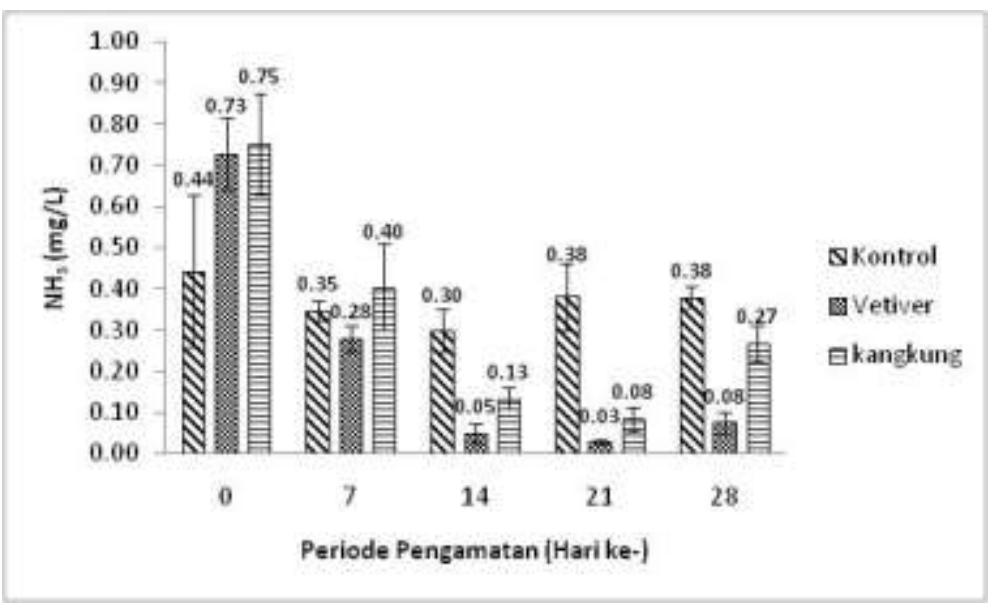

Gambar 5 Perubahan parameter kualitas air $\mathrm{NH}_{3}$. 
Hasil analisis statistik menunjukkan bahwa perlakuan berpengaruh signifikan $(\mathrm{p}<0.05)$. Pemanfaatan tanaman vetiver dan kangkung sebagai agen fitoremediasi efektif dalam menurunkan konsentrasi $\mathrm{NH}_{3}$ dalam limbah cair. Nilai removal efficiency $\mathrm{NH}_{3}$ tertinggi pada kontrol, vetiver, dan kangkung adalah $32.28 \%$, $96.16 \%$, dan $88.79 \%$.

\section{Ammonium $\left(\mathrm{NH}_{4}^{+}\right)$}

Amonium merupakan bentuk nitrogen yang dapat dimanfaatkan langsung oleh tumbuhan (Effendi 2003). Amonium dalam jumlah yang besar dalam limbah cair tidak bersifat toksik bagi tanaman. Hasil penelitian menunjukkan bahwa konsentrasi ammonium selama priode pengamatan berkisar antara 0.73-2.11 mg/L (Gambar 6).

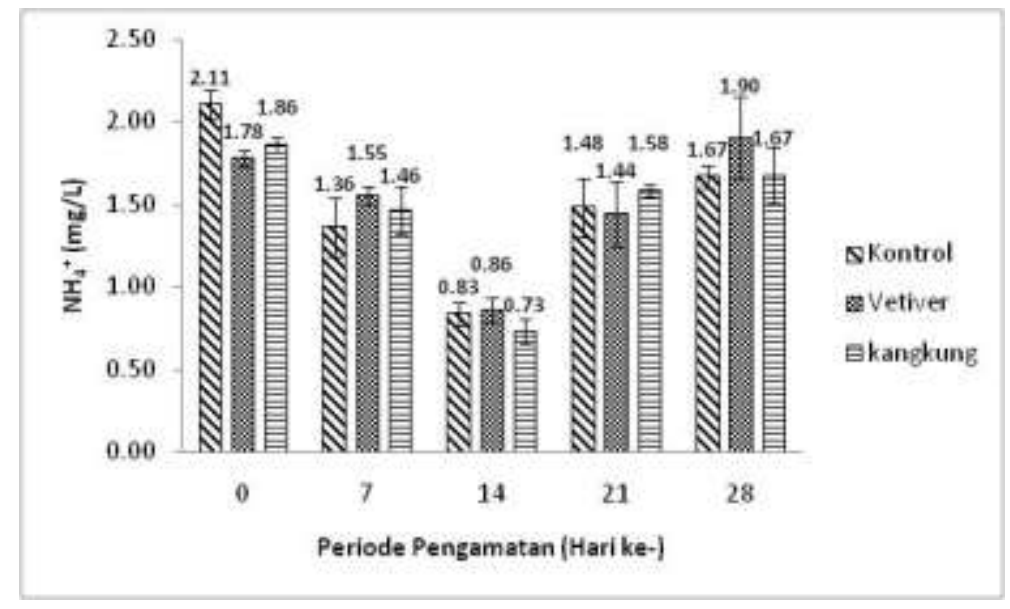

Gambar 6 Perubahan parameter kualitas air $\mathrm{NH}_{4}{ }^{+}$.

Konsentrasi ammonium cenderung fluktuatif selama priode pengamatan. Pada akhir pengamatan (hari ke28) kosentrasi ammonium perlakuan kontrol, vetiver, dan kangkung adalah $1.67 \mathrm{mg} / \mathrm{L}, 1.90 \mathrm{mg} / \mathrm{L}$, dan 1.67 $\mathrm{mg} / \mathrm{L}$. Penurunan konsentrasi ammonium selama priode pengamatan menunjukkan bahwa tanaman dan algae memanfaatkan ammonium yang terbentuk dalam limbah cair. Konsentrasi ammonium dalam limbah akan meningkat dengan menurunnya suhu dan $\mathrm{pH}$. Wahyuningsih et al. (2015) pada $\mathrm{pH} 7$, sebagian besar ammonia total dirubah menjadi amonium. Selama priode pengamatan nilai $\mathrm{pH}$ berkisar antara 7.37-8.76, sehingga konsentrasi ammonium lebih tinggi dibandingkan ammonia bebas dalam limbah cair.

Hasil analisis statistik menunjukkan bahwa perlakuan tidak berpengaruh signifikan $(\mathrm{p}>0.05)$. Pemanfaatan tanaman vetiver dan kangkung sebagai agen fitoremediasi tidak efektif dalam menurunkan konsentrasi ammonium dalam limbah cair industri kayu lapis. Nilai removal efficiency $\mathrm{NH}_{4}$ tertinggi pada kontrol, vetiver, dan kangkung adalah 60.37\%, 51.70\%, dan 60.84\%.

\section{Nitrat $\left(\mathrm{NO}_{3}\right)$}

Nitrat merupakan bentuk utama nitrogen di perairan alami dan merupakan nutrien utama bagi pertumbuhan tanaman dan algae. Senyawa ini dihasilkan oleh proses oksidasi amonia menjadi nitrit dan nitrat oleh bakteri Nitrobacter (Effendi 2003). Hasil penelitian menunjukkan bahwa konsentrasi nitrat selama priode pengamatan adalah $3.74-14.87 \mathrm{mg} / \mathrm{L}$ (Gambar 7).

Konsentrasi nitrat selama pengamatan cenderung meningkat. Pada akhir pengamatan (hari ke-28) konsentrasi nitrat pada perlakuan kontrol, vetiver, dan kangkung adalah $12.17 \mathrm{mg} / \mathrm{L}, 14.87 \mathrm{mg} / \mathrm{L}$ dan 13.14 $\mathrm{mg} / \mathrm{L}$. Peningkatan $\mathrm{NO}_{3}$ diduga karena adanya proses nitrifikasi amonia oleh bakteri, namun nitrat yang dihasilkan tidak dimanfaatkan seluruhnya oleh tanaman sehingga terjadi akumulasi pada limbah cair. Sumber nutrien bagi tumbuhan selain $\mathrm{NO}_{3}$ adalah $\mathrm{NH}_{4}{ }^{+}$, namun tanaman dapat mereduksi $\mathrm{NH}_{4}{ }^{+}$lebih cepat dibandingkan $\mathrm{NO}_{3}$ (Effendi et al. 2015). 
Hasil analisis statistik menunjukkan bahwa perlakuan tidak berpengaruh signifikan ( $>0.05)$. Pemanfaatan tanaman vetiver dan kangkung sebagai agen fitoremediasi tidak efektif dalam menurunkan konsentrasi $\mathrm{NO}_{3}$ dalam limbah cair industri kayu lapis. Nilai removal efficiency $\mathrm{NO}_{3}$ tertinggi pada kontrol, vetiver, dan kangkung adalah $6.86 \%, 12.58 \%$, dan $19.30 \%$.

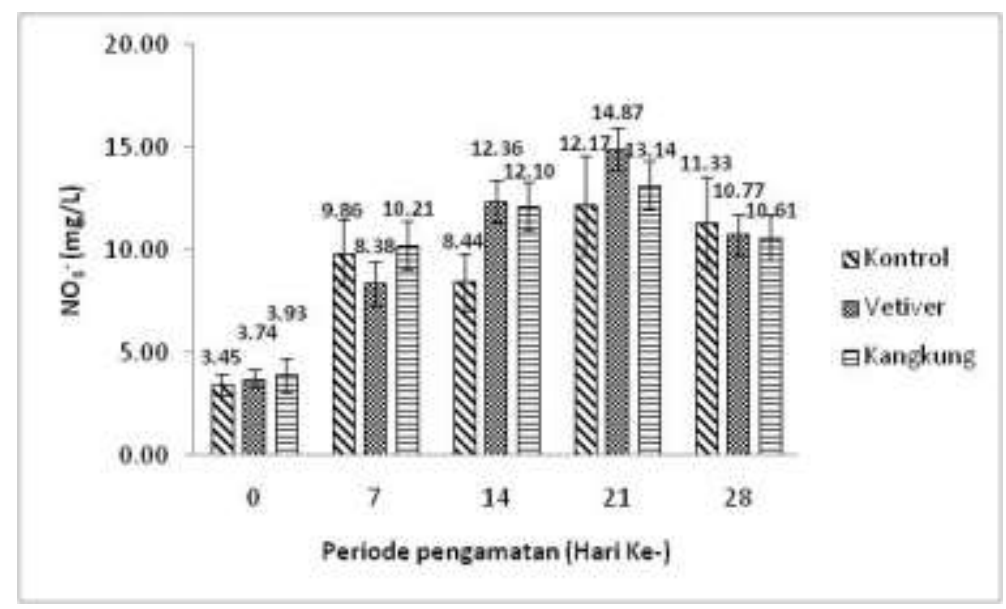

Gambar 7 Perubahan parameter kualitas air $\mathrm{NO}_{3}$.

\section{Orthopospat $\left(\mathrm{PO}_{4}\right)$}

Ortofosfat merupakan fosfat anorganik yang mampu dimanfaatkan langsung oleh organisme air maupun tumbuhan air. Menurut Effendi (2003) tingkat kesuburan suatu perairan dikategorikan kepada tingkat/level eutrof, apabila kandungan fosfat sebagai ortofosfat pada perairan berkisar antara 0.031-0.1 mg/L. Eutrofikasi merupakan peristiwa ledakan pertumbuhan tanaman air dan zooplankton dalam sistem perairan sehingga menyebabkan air menjadi keruh dan berbau, akibat dari pembusukan tumbuhan dan lumut yang mati. Hasil penelitian menunjukkan bahwa konsentrasi ortofosfat selama priode pengamatan adalah 0.63-3.00 $\mathrm{mg} / \mathrm{L}$ (Gambar 8).

Konsentrasi ortofosfat selama pengamatan cenderung meningkat. Pada akhir pengamatan (hari ke-28) kjnsentrasi ortotopospat pada kontrol, vetiver, dan kangkung adalah $1.98 \mathrm{mg} / \mathrm{L}, 2.76 \mathrm{mg} / \mathrm{L}$, dan $3.00 \mathrm{mg} / \mathrm{L}$. Peningkatan $\mathrm{PO}_{4}$ diduga karena kandungan ortopospat dalam limbah cair berlebih, sehingga tanaman membutuhkan waktu yang lebih lama dalam memanfaatkannya. Menurut Boyd (1990), penyerapan fosfor oleh fitoplankton lebih cepat dibandingkan penyerapan oleh tumbuhan air, namun tumbuhan air dapat menyerap dan menyimpan fosfor dalam jumlah yang lebih banyak. Selain itu, perubahan konsentrasi ortofosfat dalam limbah cari dipengaruhi oleh suhu dan pH. Effendi (2003) menyatakan bahwa Konsentrasi ortofosfat akan meningkat dengan peningkatan suhu dan penurunan $\mathrm{pH}$.

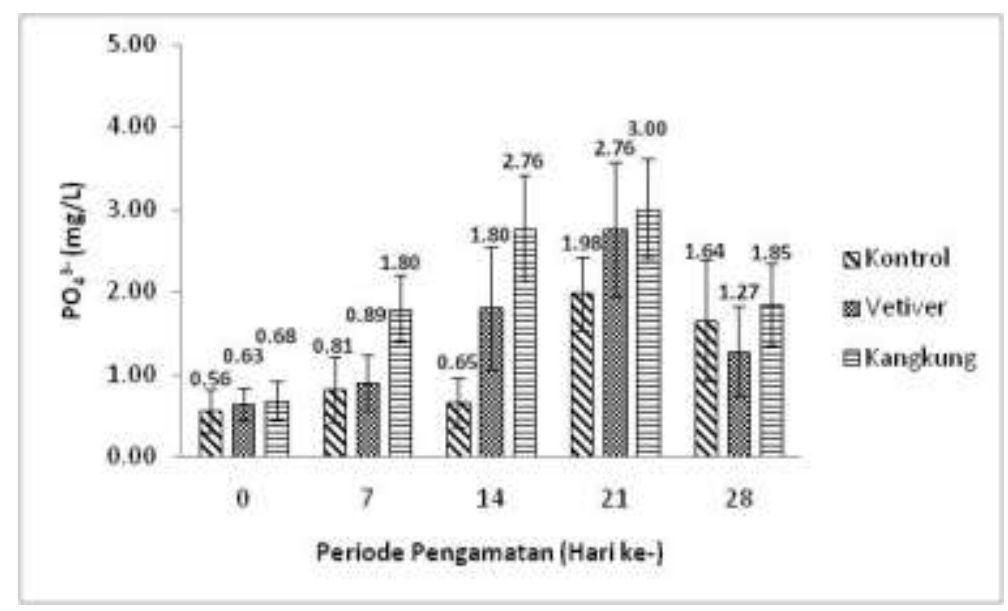

Gambar 8 Perubahan parameter kualitas air $\mathrm{PO}_{4}{ }^{3-}$. 
Hasil analisis statistik menunjukkan perlakuan berpengaruh signifikan $(\mathrm{p}<0.05)$.. Pemanfaatan tanaman vetiver dan kangkung sebagai agen fitoremediasi efektif dalam menyerap kandungan ortofosfat dalam limbah cair industri kayu lapis. Presentasi penurunan kadar ortopospat pada kontrol, vetiver, dan kangkung adalah $16.89 \%, 53.90 \%$ dan $38.39 \%$.

\section{Total Kjeldahl Nitrogen (TKN)}

Total Kjeldahl Nitrogen adalah jumlah nitrogen yang terikat dalam ammonia $\left(\mathrm{N}_{-}-\mathrm{NH}_{3}\right.$ dan $\left.\mathrm{N}-\mathrm{NH}_{4}{ }^{+}\right)$dan nitrogen dalam zat organik selain $\left(\mathrm{N}-\mathrm{NO}_{2}\right.$ dan $\left.\mathrm{N}-\mathrm{NO}_{3}\right)$. Nitrogen di perairan terdiri dari dua golongan yang berbeda bentuknya yaitu nitrogen organik dan anorganik (Boyd, 1990). Hasil penelitian menunjukkan bahwa konsentrasi TKN selama priode pengamatan berkisar antara 0.73-2.11 mg/L (Gambar 9).

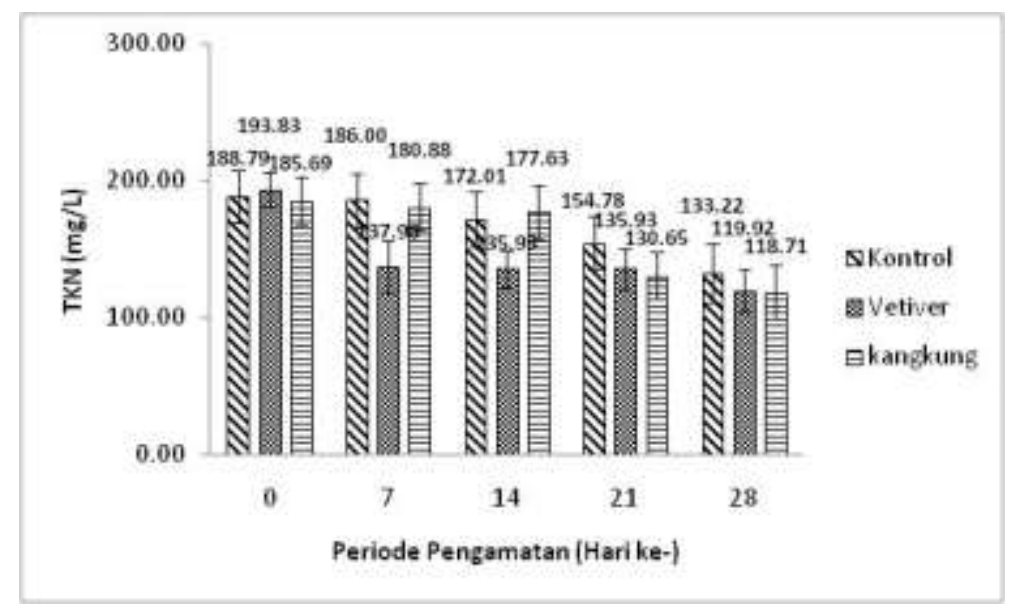

Gambar 9 Perubahan parameter kualitas air TKN.

Konsentraasi TKN cenderung menurun selama priode pengamatan. Konsentrasi TKN perlakuan kontrol, vetiver, dan kangkung pada akhir pengamatan (Hari ke-28) adalah 133.22. mg/L, $119.92 \mathrm{mg} / \mathrm{L}$, dan 118.71 $\mathrm{mg} / \mathrm{L}$. Penurunan konsentrasi TKN diduga karena adanya proses penguraian dan penyerapan senyawa nitrogen oleh mikroorganisme dan tanaman pada limbah cair. Mikroorganisme menguraikan senyawa nitrogen dalam limbah cair menjadi energi, bahan sel baru, air, dan karbondioksida (Heriyanto. 2006). Tanaman tidak dapat memanfaatkan secara langsung senyawa nitrogen dalam limbah cair dan harus mengalami fiksasi terlebih dahulu menjadi amonia $\left(\mathrm{NH}_{3}\right)$, amonium $\left(\mathrm{NH}_{4}{ }^{+}\right)$, dan nitrat $\left(\mathrm{NO}_{3}^{-}\right)$(Putri et al. 2014).

Hasil analisis sidik ragam menunjukkan bahwa perlakuan berpengaruh signifikan $(\mathrm{p}<0.05)$. Pemanfaatan tanaman vetiver dan kangkung sebagai agen fitoremediasi efektif dalam menurunkan konsentrasi TKN dalam limbah cair. Nilai removal efficiency TKN pada kontrol, vetiver, dan kangkung adalah $29.43 \%$, 38.13\%, dan $36.07 \%$.

\section{Fenol}

Fenol merupakan senyawa organik yang mempunyai gugus hidroksil yang terikat pada cincin benzena. Senyawa ini merupakan turunan dari benzena melalui penggantian gugus hidrogen dengan hidroksil, sehingga senyawa ini sering disebut hidroksi benzene (Nair et al. 2008). Fenol adalah salah satu polutan yang sangat berbahaya dengan tingkat toksisitas yang tinggi bahkan pada konsentrasi yang rendah (Singh et al. 2006). 


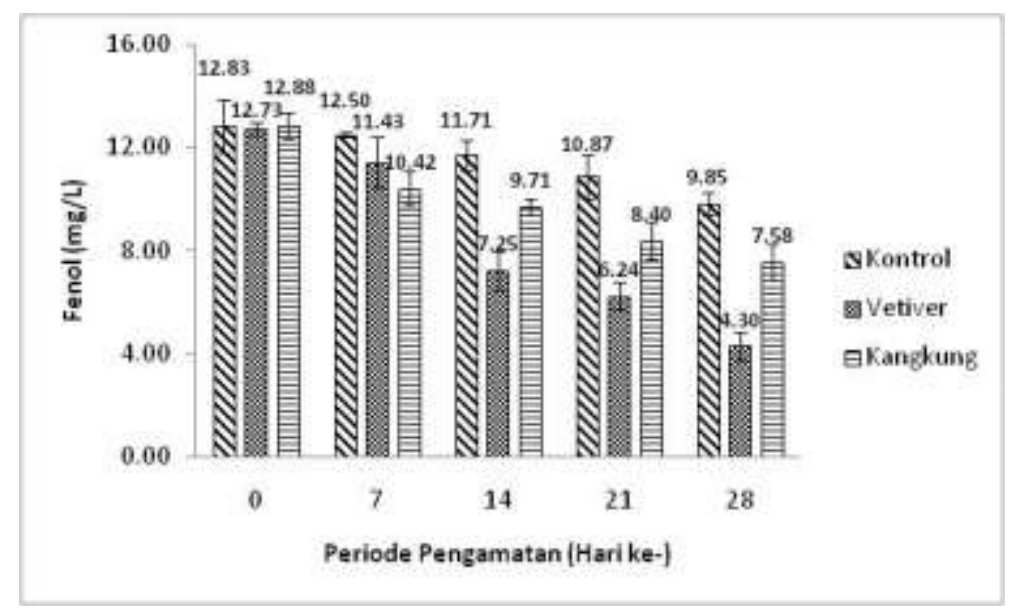

Gambar 10 Perubahan parameter kualitas air Fenol.

Konsentrasi fenol selama priode pengamatan berkisar antara 4.30-12.88 mg/L (Gambar 4). Pada akhir pengamatan (hari ke-28) konsentrasi fenol perlakuan kontrol, vetiver, dan kangkung adalah $9.85 \mathrm{mg} / \mathrm{L}, 4.30$ $\mathrm{mg} / \mathrm{L}$, dan $7.58 \mathrm{mg} / \mathrm{L}$. Nilai tersebut diatas baku mutu air limbah untuk industri kayu lapis yang mensyaratkan nilai fenol kurang dari $0.25 \mathrm{mg} / \mathrm{L}$ (KLHK No 5 tahun 2014). Penurunan konsentrasi fenol dapat terjadi karena adanya degradasi senyawa fenol dengan bantuan mikroorganisme dan tanaman pada limbah cair. Beberapa mikroorganisme memiliki kemampuan mendegradasi fenol seperti bakteri, jamur, khamir, dan alga (Ma et al. 2010; Ghanem et al. 2009; Wang et al. 2009; dan Pinto et al. 2002). Beberapa tanaman yang memiliki enzim peroksidase pada akar seperti Daucus carota (Araujo et al. 2002), Brassica napus (Agostini et al. 2003) dan Brassica juncea (Singh et al. 2006) telah digunakan dan terbukti menghilangkan fenol atau turunannya dari larutan.

Hasil analisis statistik menunjukkan bahwa perlakuan kontrol, vetiver, dan kangkung memberikan pengaruh berbeda nyata $(\mathrm{p}<0.05)$ terhadap konsentrasi fenol pada limbah cair. Pemanfaatan tanaman vetiver dan kangkung sebagai agen fitoremediasi efektif dalam menurunkan konsentrasi fenol dalam limbah cair industri kayu lapis. Nilai removal efficiency fenol perlakuan kontrol, vetiver, dan kangkung adalah 23.24\%, $66.19 \%$, dan $41.18 \%$.

\section{Model Matematika}

Pada penelitian ini model matematika digunakan untuk memprediksi potensi tanaman $C$. zizanioides (L.) dan I. aquatica Forsk dalam meremediasi beberapa parameter kualitas air untuk limbah industri kayu. Model matematika Kumar et al. 2005 digunakan pada parameter yang mengalami perubahan secara eksponensial. Parameter kualitas air dan pertumbuhan tanaman yang dapat dimodelkan adalah COD, TSS, Fenol, penambahan berat dan panjang akar.

Perbandingan antara nilai estimasi dan nilai pengamatan dari parameter COD, TSS, dan fenol memiliki variasi minimum (Gambar 5). Peningkatan durasi fitoremediasi pada parameter COD, TSS, dan fenol menghasilkan nilai pengamatan yang berbeda dengan nilai estimasi. Hal ini menunjukkan bahwa durasi fitoremediasi tanaman akan mencapai tingkat kesetimbangan penyerapan atau degradasi polutan dalam limbah.

Berdasarkan penelitian ini, model yang diusulkan berguna dalam memprediksi tren potensi fitoremediasi C. zizanioides (L.) dan I. aquatica Forsk untuk limbah industri kayu dan industri sejenis lainnya pada interval waktu apa pun. Model ini dapat membantu dalam pemantauan cepat terhadap polusi industri. Model matematis yang disajikan di sini menunjukkan ukuran remedial yang cukup akurat untuk pencemaran air limbah industri menggunakan tanaman seperti C. zizanioides (L.) dan I. aquatica Forsk, yang dapat digunakan secara menguntungkan untuk meremediasi efek buruk limbah cair industri kayu, setidaknya pada basis eksperimental. 


\section{Laju Pertumbuhan Tanaman}

Pengamatan laju pertumbuhan tamanan dilakukan untuk melihat kondisi tanaman selama periode perlakuan. Laju pertumbuhan relatif tanaman (RGR) berdasarkan berat basah tanaman vetiver dan kangkung adalah $0.011 \pm 0.002 \mathrm{~g} /$ hari dan $0.007 \pm 0.001 \mathrm{~g} /$ hari (Tabel 1). Hasil analisis statistik menunjukkan bahwa penambahan berat basah dan laju pertumbuhan relatif tanaman vetiver dan kangkung berbeda nyata $(\mathrm{p}<0.05)$. Hal ini menunjukkan bahwa tanaman vetiver memiliki kemampuan hidup lebih baik dibandingkan dengan tanaman kangkung pada limbah industri kayu. Hasil ini berbeda dengan penelitian Jampeetong et al. (2012) yang menunjukkan bahwa nilai RGR tanaman kangkung $(0.035 \pm 0.002 \mathrm{~g} / \mathrm{hari})$ lebih tinggi dibandingkan tanaman vetiver $(0.020 \pm 0.003 \mathrm{~g} / \mathrm{hari})$.

Laju pertumbuhan panjang akar harian (DGR) tanaman vetiver dan kangkung adalah $0.019 \pm 0.003 \mathrm{~cm} / \mathrm{hari}$ dan $0.012 \pm 0.006 \mathrm{~cm} /$ hari. Hasil analisis statistik menunjukkan bahwa penambahan panjang akar dan laju pertumbuhan panjang akar harian tanaman vetiver dan kangkung berbeda nyata ( $\mathrm{p}<0.05)$. Hal ini menunjukkan bahwa tanaman vetiver memiliki kemampuan yang lebih baik dalam menyerap nutrien dibandingkan dengan kangkung. Effendi et al. (2015) menyatakan bahwa akar yang lebih panjang akan memberikan peluang untuk menyerap nutrisi. Selain itu, tanaman vetiver berpotensi sebagai biofilter untuk menyerap bahan organik (Delis et al. 2015).

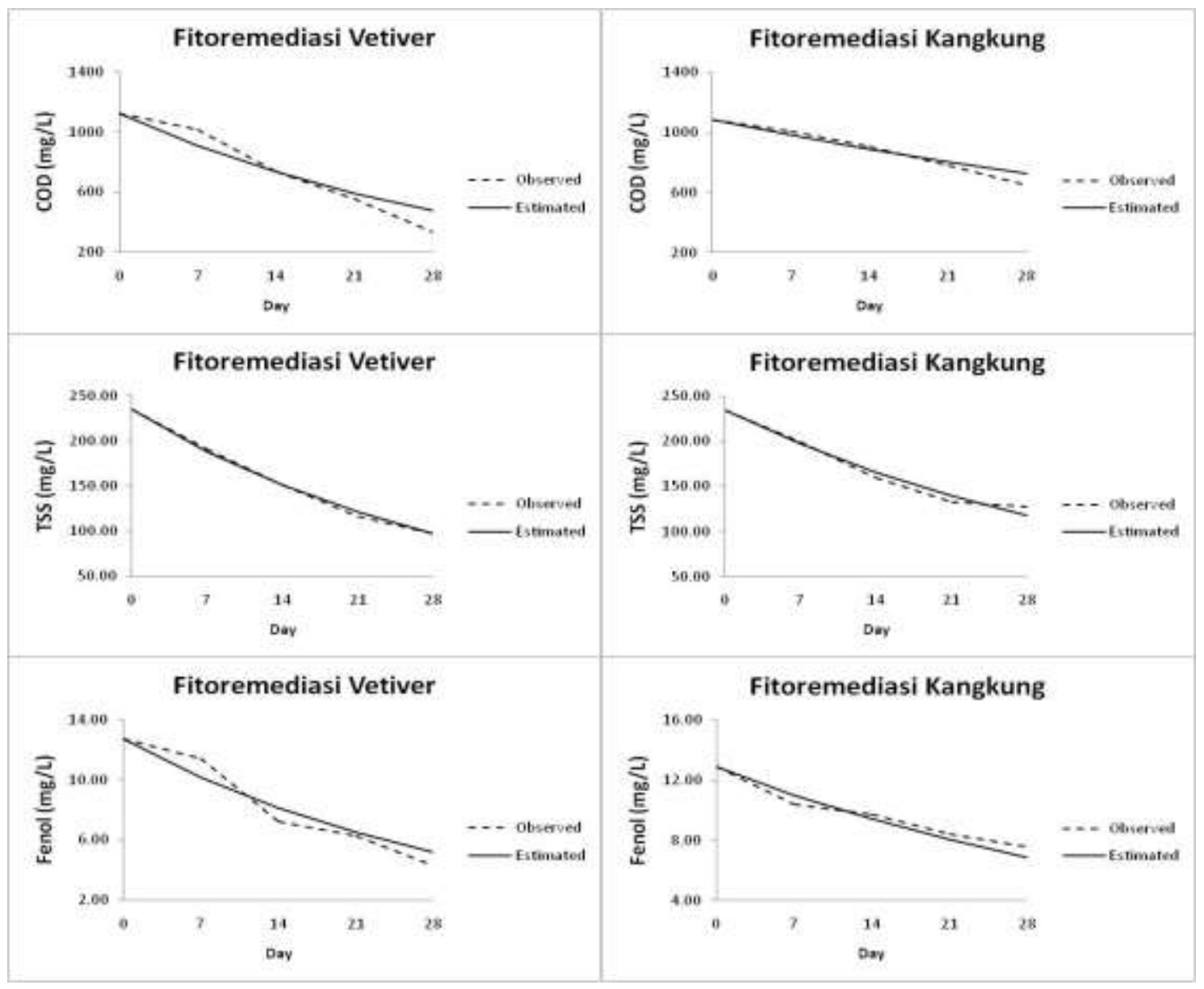

Gambar 11 Nilai estimasi dan pengamatan kualitas air. 
Tabel 2 Laju pertumbuhan tanaman

\begin{tabular}{|c|c|c|c|}
\hline \multirow{2}{*}{ Parameter } & \multirow{2}{*}{ Satuan } & \multicolumn{2}{|c|}{ Jenis Tanaman } \\
\hline & & Vetiver & Kangkung \\
\hline Berat awal $\left(\mathrm{W}_{\mathrm{o}}\right)$ & $\mathrm{g}$ & $30.04 \pm 0.09$ & $30.06 \pm 0.09$ \\
\hline Berat $\operatorname{akhir}\left(\mathrm{W}_{\mathrm{t}}\right)$ & $\mathrm{g}$ & $40.57 \pm 2.10^{\mathrm{a}}$ & $36.90 \pm 1.19^{b}$ \\
\hline Panjang akar awal $\left(\mathrm{H}_{\mathrm{o}}\right)$ & $\mathrm{cm}$ & $8.83 \pm 0.39$ & $9.33 \pm 0.41$ \\
\hline Panjang akar akhir $\left(\mathrm{H}_{\mathrm{t}}\right)$ & $\mathrm{cm}$ & $9.62 \pm 1.09^{\mathrm{a}}$ & $7.83 \pm 1.53^{\mathrm{b}}$ \\
\hline RGR & g/hari & $0.011 \pm 0.002^{\mathrm{a}}$ & $0.007 \pm 0.001^{b}$ \\
\hline DGR & $\mathrm{cm} /$ hari & $0.019 \pm 0.003^{\mathrm{a}}$ & $0.012 \pm 0.006^{\mathrm{b}}$ \\
\hline
\end{tabular}

- Huruf Superscript merupakan hasil uji Duncan pada taraf 5\%

\section{Korelasi Pearson}

Hubungan yang menggambarkan efisiensi penyisihan parameter kualitas air (suhu, pH, TSS, COD, TAN, $\mathrm{NH}_{3}, \mathrm{NH}_{4}{ }^{+}, \mathrm{TKN}, \mathrm{NO}_{3}{ }^{-}, \mathrm{PO}_{4}{ }^{3-}$, dan Fenol) dengan parameter pertumbuhan tanaman (bobot basah, panjang akar, RGR, dan DGR).

Efisiensi COD memiliki korelasi positif terhadap berat dan panjang akar tanaman yaitu 0.977 dan 0.981 (sangat kuat). Hal ini menunjukkan bahwa semakin tinggi efisiensi penyisihan COD pada limbah cair maka semakin tinggi berat dan panjang akar tanaman. Parameter $\mathrm{pH}$ memiliki korelasi negatif terhadap penambahan berat dan panjang akar tanaman yaitu -0.833 dan -0.866 . Hal ini menunjukkan bahawa semakin tinggi nilai $\mathrm{pH}$ dalam limbah cair maka semakin rendah berat dan panjang akar tanaman. Tanaman vetiver dapat tumbuh pada kondisi lingkungan dengan pH 6-9 (Sigh et al. 2014) dan tanaman kangkung 5.5-7 (Lestari. 2013).

Efisiensi penyisihan $\mathrm{NH}_{3}$ memiliki korelasi positif terhadap berat dan panjang akar tanaman yaitu 0.839 dan 0.797 (sangat kuat). Hal ini menunjukkan bahwa semakin tinggi efisiensi penyisihan $\mathrm{NH}_{3}$ dalam limbah cair maka semakin tinggi berat dan panjang akar tanaman. Effendi (2003) menyatakan ammonia bebas $\left(\mathrm{NH}_{3}\right)$ dalam limbah cair bersifat toksik terhadap organisme perairan, sedangkan amonium $\left(\mathrm{NH}_{4}{ }^{+}\right)$tidak berbahaya dan merupakan bentuk yang dapat dimanfaatkan oleh tumbuhan sebagai sumber nutrien.

Tabel 3 Korelasi parameter kualitas air dan pertumbuhan tanaman.

\begin{tabular}{|c|c|c|c|c|c|c|c|c|}
\hline Parameter & $\mathrm{pH}$ & TSS & COD & $\mathrm{NH}_{3}$ & TKN & Fenol & Berat Basah & Panjang Akar \\
\hline $\mathrm{pH}$ & 1 & $-.708^{*}$ & $-.858^{* *}$ & $-.859^{* *}$ & $-.758^{*}$ & $-.873^{* *}$ & $-.873^{* *}$ & $-.833^{* *}$ \\
\hline TSS & $-.708^{*}$ & 1 & $.784^{* *}$ & $.820^{* *}$ & $.755^{*}$ & $.841^{* *}$ & $.841^{* *}$ & $.854^{* * *}$ \\
\hline COD & $-.858^{* *}$ & $.784^{* *}$ & 1 & $.753^{*}$ & $.817^{* *}$ & $.977^{* *}$ & $.977^{* *}$ & $.981^{* *}$ \\
\hline $\mathrm{NH}_{3}$ & $-.859^{* *}$ & $.820^{* * *}$ & $.753^{*}$ & 1 & $.740^{*}$ & $.839^{* *}$ & $.839^{* *}$ & $.797^{* * *}$ \\
\hline TKN & $-.758^{*}$ & $.755^{*}$ & $.817^{* *}$ & $.740^{*}$ & 1 & $.786^{* *}$ & $.786^{* *}$ & $.853^{* *}$ \\
\hline Fenol & $-.873^{* *}$ & $.841^{* *}$ & $.977^{* *}$ & $.839^{* *}$ & $.786^{* *}$ & 1 & $.966^{* *}$ & $.988^{* *}$ \\
\hline Berat Basah & $-.873^{* *}$ & $.841^{* *}$ & $.977^{* *}$ & $.839^{* *}$ & $.786^{* *}$ & $.966^{* *}$ & 1 & $.966^{* *}$ \\
\hline Panjang Akar & $-.833^{* *}$ & $.854^{* * *}$ & $.981^{* *}$ & $.797^{* *}$ & $.853^{* *}$ & $.988^{* *}$ & $.966^{* *}$ & 1 \\
\hline
\end{tabular}

* Correlation is significant at the 0.05 level (2-tailed)

** Correlation is significant at the 0.01 level (2-tailed)

Efisiensi penyisihan TSS dengan berat dan panjang akar tanaman memiliki korelasi positif yaitu 0.841 dan 0.854 (sangat kuat). Hal ini menunjukkan bahwa semakin tinggi efisiensi penyisihan TSS maka berat dan panjang akar tanaman semakin tinggi. Effendi (2003) menyatakan nilai TSS yang tinggi akan menghambat sinar matahari ke dalam wadah percobaan sehingga mempengaruhi proses respirasi dan proses fotosintesis tanaman menjadi terhambat. 
Efisiensi penyisihan fenol dengan berat dan panjang akar tanaman memiliki korelasi positif yaitu 0.966 dan 0.988 (sangat kuat). Hal ini menunjukkan bahwa semakin tinggi efisiensi penyisihan fenol maka bobot basah dan penambahan akar tanaman semakin tinggi. Pada konsentrasi tertentu, fenol dapat menghambat pertumbuhan akar (Ratsch. 1983), akar berwarna coklat (Jha et al. 2013), dan perkecambahan biji tanaman (Ibanez et al. 2012).

\section{SIMPULAN}

Kesimpulan yang didapatkan pada penelitian Potensi Rumput Vetiver (Chrysopongon zizanoides L.) dan Kangkung (Ipomoea aquatica Forsk.) sebagai Agen Fitoremediasi Limbah Industri Kayu adalah sebagai berikut:

1. Tanaman vetiver dan kangkung memiliki kemampuan meremediasi Total Suspended Solid (TSS), Chemical Oxygen Demand (COD), amonia bebas $\left(\mathrm{NH}_{3}\right)$, orthopospat $\left(\mathrm{PO}_{4}{ }^{3-}\right)$, Total Kejldahl Nitrogen (TKN), dan fenol pada limbah industri kayu, removal efficiency tertinggi adalah $\mathrm{NH}_{3}$ dan terendah TKN.

2. Efisiensi penyisihan Parameter kualitas limbah industri kayu TSS, COD, $\mathrm{NH}_{3}, \mathrm{TKN}$, dan fenol memiliki korelasi positif terhadap pertumbuhan tanaman berdasarkan berat basah dan panjan akar, sedangkan $\mathrm{pH}$ berkorelasi negatif.

3. Tren potensi fitoremediasi C. zizanioides (L.) dan I. aquatica Forsk dalam mendegradasi COD, TSS, dan fenol untuk limbah industri kayu dapat digambarkan pada model matematika.

\section{DAFTAR PUSTAKA}

[APHA] 2012. Standard Methods for the Examination of Water and Wastewater, $22^{\text {nd }}$ edition.

[KLHK] Kementrian Lingkungan Hidup Republik Indonesia. 2014. Peraturan Menteri Lingkungan Hidup Republik Indonesia Nomor 5 Tahun 2014 tentang Baku Mutu Air Limbah. Jakarta: Kementrian LH.

Agostini E, Coniglio MS, Milrad SR, Tigier HA, Giulietti AM, 2003. Phytoremediation of 2,4-dichlorophenol by Brassica napus hairy root cultures. J. Biotechnol. Appl. Biochem. 37: 139-144.

Aibibu N, Yunguo L, Guangming Z, Xin W, Beibei C, Huaxio S, Li X. 2010. Cadmium accumulation in vetiveria zizanioides and its effects on growth, physiological and biochemical characters. Bioresource Technology. 101(1): 6297-6303.

Alaerts G, Santika SS. 1987. Metode Penelitian Air. Surabaya: Penerbit Usaha Nasional.

Araujo BS, Charlwood BV, Pletsch M. 2002. Tolerance and metabolism of phenol and chloroderivatives by hairy root cultures of Daucus carota L. Int. Jurnal Environ Pollut. 117(2): 329-335.

Boyd CE. 1990. Water Quality in Ponds for Aquaculture. Brimingham: Birmingham Publishing Co.

Chen JC, Wang KS, Chen H, Lu CY, Huang LC, Li HC, Peng TH, Chang SH. 2010. Phytoremediation of $\mathrm{Cr}$ (III) by Ipomonea aquatica (water spinach) from water in the presence of EDTA and chloride: effects of Cr speciation. J. Biotechnol. 101(9): 3033-3039.

Crab R, Avnimelech Y, Defoidt T, Bossier P, Verstraete. 2007. Nitrogen removal techniques in aquaculture for a sustainable production. J. Aquaculture. 270: 1-14.

Delis PC, Effendi H, Krisanti M, Hariyadi S. 2015.Treatment of aquaculture wastewater using Vetiveria zizanioides (Liliopsida, Poaceae). Int. J. ACCL Bioflux. 8(4): 616-625.

Effendi H, Utomo BA, Darmawangsa GM, Karo-Karo RE. 2015. Fitoremediasi limbah budidaya ikan lele (Clarias sp) dengan kangkung (Ipomoea aquatica) dan pakcoy (Brassica rapa chinensis) dalam sistem resirkulasi. J. Ecolab. 9:47-104.

Effendi H. 2003. Telaah Kualitas limbah cair Bagi Pengelolaan Sumberdaya dan Lingkungan Perairan. Yogyakarta: Kanisius.

Fachrurozi M, Utami LB, Suryani D. 2010. Pengaruh variasi biomassa Pistia stratiotes L. terhadap penurunan kadar BOD, COD, dan TSS limbah cair tahu di Dusun Klero Sleman Yogyakarta. J. Kesmas. 4(1): 1213. 
Ghanem KM, Al-Garni SM, Al-Shehri AN. 2009. Statistical optimization of cultural conditions by response surface methodology for phenol degradation by a novel Aspergillus flavus isolate. J Biotechnol. 8: 35763583.

Gunawan, H. 2009. Efisiensi penghilangan detergen dari limbah cuci pakaian oleh tanaman eceng gondok (Eichhornia crassipes) dan kiambang (Salvinia molesta) [skripsi]. Surabaya: Unversitas Surabaya.

Heriyanto. 2006. Pengaruh rasio COD/TKN pada proses denitrifikasi limbah cair industri perikanan dengan lumpur aktif [Skripsi]. Bogor: Perikanan dan Ilmu Kelautan IPB.

$\mathrm{Hu}$ MH, Ao YS, Yang XE, Li TQ. 2008. Treating eutrophic water for nutrient reduction using an aquatic macrophyte (Ipomoea aquatica Forsk) in a deep flow technique system. J. Agric. Water Manag. 95: 607-615.

Hunt R. 2017. Growth Analysis, Individual Plants. Encyclopedia. Appl. Plant Sciences. 1: 421-429.

Ibanez SG, Alderete LGS, Medina MI, Agostini E. 2012. Phytoremediation of phenol using Vicia sativa L. plants and its antioxidative response. Environmental Science and Pollution Research. 19(5): 1555-1562.

Indah LS, Hendrarto B, Soedarsono P. 2014. Kemampuan eceng gondok (Eichhornia sp), kangkung (Ipomoea sp), dan kayu apu (Pistia sp) dalam menurunkan bahan organik limbah industri tahu (skala laboratorium). J. Diponegoro of Maquares. 3(1): 1-6.

Jampeetong A, Brix H, Kantawanichkul S. 2012. Effects of inorganic nitrogen forms on growth, morphology, nitrogen uptake capacity and nutrient allocation of four tropical aquatic macrophytes (Salvinia cucullata, Ipomoea aquatica, Cyperus involucratus and Vetiveria zizanioides). J. Aquatic Botany. 97: 10-16.

Jha P, Jobby R, Kudale S, Modi N, Dhaneshwar A, Desai N. 2013. Biodegradation of phenol using hairy roots of Helianthus annuus L. International Biodeterioration and Biodegradation. 77: 106-113.

Khan S, Ahmad I, Shah MT, Rehman SH, Khaliq A. 2009.Use of constructed wetland for the removal of heavy metals from industrial wastewater.J. Environ Manage. 90: 3451.

Klibanov AM, Tu TM, Scott KP. 1983. Peroxidase catalysed removal of phenol from coal-conversion waste waters. J. Science. 221: 259-261.

Kumar K, Dube KK, Rai JPN. 2005. Mathematical model for phytoremediation of pulp and paper industry wastewater. J. Sci. Ind. Res. 64: 717-721.

Lee SY, Ahmad SA, Mustapha SR, Abdullah JO. 2017. Ability of Ipomoea aquatica Forssk. to remediate phenol in water and effects of phenol on the plant's growth. J. Sci. \& Technol. 25(2): $441-452$.

Lestari W. 2013. Penggunaan Ipomoea aquatica Forsk.untuk fitoremediasi limbah rumah tangga. Semirata 2013 FMIPA Universitas Lampung. Lampung, Indonesia. pp: 441-446.

Ma H, Li G, Fang P, Zhang Y, Xu D. 2010. Identification of phenol-degrading Nocardia sp. strain C-14-1 and characterization of its ring-cleavage 2,3- dioxygenase. International Journal of Biology. 2:79-83.

Mulia MR. 2005. Kesehatan Lingkungan. Jakarta: Graha Ilmu.

Nair CI, Jayachandran K, Shashidar S. 2008. Biodegradation of phenol. African Journal of Biotechnology 7: 4951- 4958.

Pinto G, Pollio A, Previtera L, Temussi F. 2002. Biodegradation of phenols by microalgae. Biotechnology Letters. 24: 2047-2051.

Purnamawati. 2015. Penurunan kadar rhodamin B dalam air limbah dengan biofiltrasi sistem tanaman [tesis]. Bali: Pascasarjana Universitas Udayana.

Putri FDM, Widyastuti E, Christiani. 2014. Hubungan perbandingan total nitrogen dan total fosfor dengan kelimpaan Chrysophyta di perairan waduk panglima besar Soedirman, Banjarnegara. J. Scripta biologica. 1(1): 96-101.

Rahadian R, Sutrisno E, Sumiyati S. 2017. Efisiensi penurunan COD dan TSS dengan fitoremediasi menggunakan tanaman kayu apu (Pistia stratiotes L) Studi Kasus: Limbah Laundry. J. Teknik Lingkungan. 3(6): 1-8.

Ratsch HC. 1983. Interlaboratory root elongation testing of toxic substances on selected plant species.J. Env. Protection Agency. 600: 3-85. 
Ridha MT, Cruz EM. 2001. Effect of biofilter media on water quality and biological performance of the nile tilapia Oreochromis niloticus L. reared in a simple recirculating system. J. Aquaculture Engineering. 24: 157-166.

Singh S, Melo JS, Eapen S, D’Souza SF. 2006. Phenol removal by Brassica juncea hairy roots: role of inherent peroxidase and H2O2. J. Biotechnol. 123 (1): 43-49.

Singh S, Melo JS, Eapen S, D'Souza SF. 2008. Potential of vetiver (Vetiveria zizanoides L. Nash) for phytoremediation of phenol.J. Ecotoxicology and Environmental Safety. 71: 671-676.

Strickland JDH, Parsons TR. 1972. A Practical Handbook of Seawater Analysis. Ottawa: Fisheries Research Board of Canada.

Surtiningsih. 2009. Mengenal lebih dekat rumput vetiver. Bul BPKSDM. 2: 16.

Terry N, Banuelos GS. 2010. Phytoremediation of Contaminated Soil and Water. USA: Lewis Publisher.

Truong P. 2000.The global input of vetiver grass technology on the environment. In: Proceedings of the Second International Conference on Vetiver, Bangkok. pp: 46-57.

Wahyuningsih S, Effendi H, Wardiatno Y. 2015. Nitrogen removal of aquaculture wastewater in aquaponic recirculation system.Int. J. ACCL Bioflux. 8(4): 491-499.

Wang G, Wen J, Li M, Qiu C. 2009. Biodegradation of phenol and m-cresol by Candida albicans PDY-07 under anaerobic condition. J Ind Microbiol Biotechnol 36: 809-814.

Wang KS, Huang LC, Lee HS, Chen PY, Chang SH. 2008. Phytoextraction of cadmium by Ipomoea aquatica (water spinach) in hydroponic solution: effects of cadmium speciation. J. Chemosphere. 72(4):666-672. 